\title{
ALGUNS PROBLEMAS DA UNIVERSIDADE DE SÃo PAULO *
}

\author{
Jorge Americano **
}

Agradeço ao querido amigo Prof. Ayroza Galvão as bondosas referências que fêz a mim quando há pouco se referiu a fundação da Faculdade de Higiene e Saúde Pública. Sendo eu, àquele tempo, Reitor da Universidade, e encontrando no então Instituto de Higiene, um grupo seleto de professôres, entre os quais o saudoso Geraldo de Paula Souza, eu teria faltado a un dever precípuo para com a Universidade, se não procurasse favorecer, na medida das minhas forças a elevação do Instituto de Higiene em Faculdade, e nada mais fiz do que isso.

Escolhi para tema desta palestra "Alguns Problemas da Universidade de São Paulo".

Ao ser criada a Universidade de São Paulo, há vinte e cinco anos, ela surgiu pela juxtaposição de várias instituiçôes de ensino superior que the preexistiam, como as Faculdades de Direito, de Farmácia, a de Medicina, a Escola Politécnica e a Escola Superior de Agricultura, às quais se acrescentou a então criada Faculdade de Filosofia, Ciências e Letras.

Dessa circunstância resultou que continuando () distanciamento físico, difícil foi, e por muito tempo persistirá o afastamento afetivo e o desinterêsse cultural reciproco. Cada professor continuou a considerar-se apenas professor da sua Faculdade, e não se sentiu integrado no conjunto universitárịo, pois a tradição a que se vinculára não se quebraria, nem convinha quebrar-se pela criação de un novo organismo, êste, sim, ainda sem tradição, pois que recém-nascido, a Universidade.

O primeiro reitor, o saudoso Reinaldo Porchat, numa gestão de três anos, arcou com os problemas iniciais de organização e administração c abordou a coordenação e aproximação física com a criação do escritório técnico da Cidade Universitária, chefiado pelo Prof. Souza Campos.

O segundo, o saudoso Rubião Meira, reitor por outros três anos, procurou prosseguir criando a Associação dos Professores, a fin de incre-

* Resumo da palestra realizada na Fac. Hig. e S. Pública da U.S.P. em 22-7-54 en comenoraça do ano jubiliar da Universidade de São Paulo.

* Professor catedrático de Direito Civil da Fac. de Direito da L.S.P. 
mentar a formação do espírito universitário, mas infelizmente a Associação durou pouco.

A terceira gestão, do Prof. Lúcio Martins Rodrigues não durou mais que poncos meses, de modo que, ao assumir cu a Reitoria em 1941 o assunto estava ainda no comêço.

Durante os cinco anos e pouco em que exercí o cargo pude conlecer () assunto e dar-lhe certo incremento, com a recente designação da área da fazenda Butantã para o "campus" universitário, conclição sine qua non de uma verdadeira vida universitária.

A experiência norte-americana demonstrára as vantagens de afastar as Universidades dos grandes centros. A de Princeton foi pràticamente instalada em pleno campo. A de Pennsilvania, instalada fora da cidade de Filadelfia, foi alcançada pelo crescimento desta cidade.

A de Columbia, em Nova York, já de há muito foi envolvida pela urbs. Mas as Universidades de Cornell e de Ann Arbor têm as pequenas cidades vizinhas como seus satélites.

Quais as vantagens ou desvantagens da contiguidade ou do afasta.mento entre as Universidades e os grandes centros?

Por um lado, o grande centro contíguo atrai as atividades e interêsses pelas grandes atrações que oferece, quer para o corpo docente como para o discente e administrativo.

Não é fácil renunciar a um grande centro com tôda a sua vis atrativa, para morar em local distante, abstraindo de relaçoes, amizades, diversões e recursos urbanos.

Só una grande compensação de outra ordem pode demover o advogado de renome, o clínico famoso, o técnico afamado, de se manter em contacto com o centro urbano de onde the vem o prestígio, a tama e a riqueza. Daí poder-se concluir, não pela solução de afastamento longíquo, mas pela contiguidade delimitada, como foi o caso da Cidade Universitária da Universidade de São Paulo.

Dentro desta, como elementos de atração e coordenação, que substituam as vantagens das grandes cidades, haverá núcleos residenciais para professores e funcionários bem como dormitórios e residências para alunos. Ademais, todo o conforto necessário à família, tal como a criche, o jardim da infância, os cursos prí-primário e primário, o ginásio de aplicação, enfim, todo o sistema educacional que vincula a família ao meio em que vive.

Conseqüentenente, há de considerar a orientação vocacional que envolve, não só o problema do estudante normal, como o do desajustado, na pesquisa de suas causas e adequados remédios. 
Porque certos alunos são máus, porque certas aulas são indisciplinadas? Desajustamento do aluno? Deficiência do professor? Dificuldades provenientes da família do aluno ou do professor?

Tudo isso é vastíssimo tema a abordar e resolver.

Surge correlatamente o problema da vida social interna.

A familia do professor, que não tem recursos para frequentar a alta sociedade de fortuna, tê-lo-á na Universidade, onde não existirá a competição do luxo, e onde é possivel manter relações de alto nível cultural dentre as próprias relações e amizades geradas na convivência quotidiana.

Corais, orquestras, representações dramáticas, bailes, cinemas, tudo isso tem que existir, a fim de compensar o afastamento dos grandes centros populosos.

Campos de esportes, educação física, assistência social, serão outros tantos elementos indispensáveis à vida universitária, de modo que se façam normalmente as relações entre jovens de ambos os sexos, propiciando-lhes a formação das futuras famílias, bem como criando para êles, nos contactos diários com os professôres, novos lares cimentados pela amizade recíproca.

Mas deixando isso tudo apenas esboçado, passemos aos problemas de ensino e da pesquisa.

O maior inimigo da pesquisa e do ensino ć a rotina.

Quanto ao ensino, especialmente nas aulas teóricas, há muito a desejar na nossa Universidade. É indispensável que o professor seja accessível, não se distancie do aluno, conheça-o, converse com êle.

A interrupção que às vêzes o aluno faz enl aula para esclarecer-se em certo ponto, nem sempre é recubida com simpatia pelo professor, e esta sua atitude obsta a que o professor possa sondar, não só a adequação do nivel da aula aos alunos, como também a receptividade dêste. Embora caiba ao assistente da cadeira a explicação das questões não apreendidas pelo aluno, incumbe ao catedrático esclarecê-lo diretamente, sempre que possivel, de forma que o distanciamento entre docentes e discentes ć um grande mal. Tôda vez que o professor sc recusar a esclarecer uma questão proposta pelo aluno, o professor prejudica sua reputação, aparentando ignorância da matéria, traduzida en desprestígio perante o corpo discente.

Quanto à pesquisa, a qual jamais prolifera na mentalidade burocrática, o seu incremento depende de bom material e aparelhamento, boas nor- 
mas de trabalho, paz de espírito no pesquisador, afastamento de todo o impeço burocrático e rotineiro.

O sistema obsoleto dos empenhos de verba atúa na razão inversa da produção científica. Quanto mais rotina, menos produção.

Há professôres nesta Universidade, que tem tirado dinheiro do seu bolso, com imenso sacrifício, para a aquisição de material, à falta de dotações orçamentárias, ou diante da burocracia rotineira que leva meses e meses para empenhar verbas, paralisando por igual tempo o prosseguimento de uma pesquisa e gerando o desânimo no espírito do pesquisador.

Dai o surgimento do professor também burocrático que se vangloria da boa aparência do seu laboratório, em que nada se produz, ou daquele professor que passa a vida a lamentar-se, tanto nas conversações como nos extensíssimos relatórios que elabora, da falta de material ou de aparelhamento para poder trabalhar.

Na minha gestão como reitor tive a oportunidade de, com o auxilio e a orientação que me deram excelentes companheiros, organizar os "Fundos Universitários de Pesquisas", entidade esta que subvenciona diretamente os departamentos universitários absolutamente livre das complicações burocráticas. Os resultados foram excelentes e aquele quinquênio da guerra foi de intensa produção científica.

Mas outras administrações vieram. A Constituição do Estado mandou consignar para pesquisas meio por cento da arrecadação global do Estado.

Essa determinação constitucional até agora não foi cumprida. Mas os Fundos Universitários não puderam prosseguir após o têrmo da guerra e àquela emancipação científica que vinha nascendo, sucedeu a intensificação da rotina, em detrimento da pesquisa.

Parece indispensável, entretanto, que independentemente dos fundos oficiais que sejam ou venham a ser votados para a pesquisa científica, também as entidades particulares, especialmente industriais, se interessem e contribuam, de vez que não prescindem do desenvolvimento técnico-cientifico para o desenvolvimento das suas próprias atividades.

Não abordarei aqui outros problemas, como o do intercâmbio de alunos, o intercâmbio de professôres, o aliciamento do corpo docente e os processos de concurso.

Espero que esta ligeira contribuição, comemorativa dos vinte e cinco anos da fundação da Universidade, atráia o interêsse dos universitários em geral, a fim de que, transposta a sua difícil fase inicial, possamos abrir terreno propício para o pensamento criador de que depende a grandeza do Brasil. 